\title{
Employment status of people diagnosed with multiple sclerosis in Brazil
}

\author{
Situação de empregabilidade em pessoas com esclerose múltipla no Brasil \\ Carolina Martines ESTRUTTI', Gustavo San Martin Elexpe CARDOSO², Maykon Anderson Pires de NOVAIS', \\ Enedina Maria Lobato de OLIVEIRA4 ${ }^{4}$, Denis Bernardi BICHUETTI ${ }^{4}$
}

\begin{abstract}
Objective: To describe the employment status of Brazilians with multiple sclerosis (MS). Methods: Analysis of a cross-sectional online survey including questions on demographic and occupational status at the time of diagnosis and survey completion, and time from the first symptom to diagnosis. Results: Of those who answered the survey, 804 Brazilians with MS were included. Median age of onset and current age were 28.3 and 36.2 years; median time to diagnosis and disease duration were 2.7 and 7.9 years; $67 \%$ held a university degree and $29 \%$ finished high school; $94 \%$ had a paid occupation contributing to the family income at least once in their lives, $77 \%$ were employed at the time of diagnosis but only $59 \%$ were employed at the time of survey. Longer disease duration, longer time to diagnosis and younger age at the first symptom, were identified as factors correlated with being unemployed. Conclusions: The rate of unemployment doubled after the first symptoms of MS, and only 59\% of highly-educated people with MS in their productive years were employed. The longer time to diagnosis may imply treatment delay, and strategies focusing on early diagnosis and adequate treatment may favor employment retention and reduce disability related costs, such as social benefits and pension fund use.
\end{abstract}

Keywords: Multiple sclerosis; employment, Brazil

\section{RESUMO}

Objetivo: Descrever o estado de empregabilidade de uma amostra brasileira de pessoas com esclerose múltipla (EM). Métodos: Estudo transversal incluindo informações demográficas e ocupacionais no momento do diagnóstico e atual, e o tempo do primeiro sintoma ao diagnóstico. Resultados: Foram incluídos 804 pacientes com EM, com mediana de idade de início dos sintomas e atual de 28,3 e 36,2 anos; tempo mediano para diagnóstico e duração da doença de 2,7 e 7,9 anos. Desta amostra, 67\% possuíam diploma universitário e $29 \%$ terminaram o ensino médio. No total, 94\% tiveram uma ocupação remunerada pelo menos uma vez na vida, $77 \%$ estavam empregados no diagnóstico, mas apenas 59\% estavam empregados no momento da pesquisa. Maior duração de doença, maior tempo para o diagnóstico e menor idade no $1^{\circ}$ sintoma foram os fatores relacionados ao desemprego. Conclusões: A taxa de desemprego dobra após os primeiros sintomas da EM, e apenas 59\% das pessoas com alto nível educacional com EM em seus anos produtivos estão empregados. Maior tempo para o diagnóstico pode implicar atraso no tratamento, e estratégias com foco no diagnóstico precoce e tratamento adequado podem favorecer a retenção de emprego e reduzir os custos relacionados à doença, como benefícios sociais e uso de fundos de pensão.

Palavras-chave: Esclerose múltipla; empregabilidade, Brasil

Multiple sclerosis (MS) is a chronic autoimmune, inflammatory and demyelinating disease that affects the central nervous system ${ }^{1}$. While some people with MS may live with minor disabilities, nearly $60 \%$ become unable to walk without assistance 20 years after their first symptoms ${ }^{2,3}$. The disease debuts at the peak of productive life, between 20 and 40 years

1 Universidade Federal de São Paulo, Escola Paulista de Medicina, São Paulo SP, Brasil;

${ }^{2}$ Amigos Múltiplos pela Esclerose, Guarulhos SP, Brasil;

${ }^{3}$ Universidade Federal de São Paulo, Escola Paulista de Medicina, Disciplina de Economia e Gestão em Saúde, São Paulo SP, Brasil;

«Universidade Federal de São Paulo, Escola Paulista de Medicina, Disciplina de Neurologia, Ambulatório de Neuroimunologia, São Paulo SP, Brasil.

Carolina Martines Estrutti (iD) https://orcid.org/0000-0002-4011-3734

Correspondence: Denis Bernardi Bichuetti; Disciplina de Neurologia, Escola Paulista de Medicina / UNIFESP; Rua Botucatu,740; 04023-900 São Paulo SP, Brasil; E-mail: bichuetti@unifesp.br

Conflict of interest: Carolina Martines Estrutti has received a scientific scholarship from Fapesp; Gustavo San Martin Elexpe Cardoso is the CEO of Amigos Múltiplos pela Esclerose (AME); Maykon Anderson Pires de Novais has nothing to disclose; Enedina Maria Lobato de Oliveira has received speaker fee from Teva, Biogen Idec, Sanofi-Genzyme and Novartis, travel grant from Merck; consulting honoraria from Merck, Sanofi-Genzyme; Denis Bichuetti has received speaking/consulting honoraria from Bayer Health Care, Biogen Idec, Merck, Sanofi-Genzyme, TEVA and Roche and had travel expenses to scientific meetings sponsored by Bayer Health Care, Merck Serono, TEVA and Roche.

Received 28 August 2018; Received in final form 02 November 2018; Accepted 26 February 2019. 
of age, and thus compromises the patient's quality of life and productivity, impacting negatively on personal autonomy, employment status and remuneration ${ }^{4}$.

The worldwide unemployment rates of people with MS range from $30 \%$ to $43 \%$ within 11 to 19 years of disease onset ${ }^{5,6,7,8,9}$ and work availability decreases from $82 \%$ to $8 \%{ }^{10}$. Having MS more than triples the chance of losing the current job $^{11}$, and simply publicly disclosing the MS diagnosis has a major negative impact on the chance of becoming employed or having a remunerated activity ${ }^{3,12}$.

The combined public and individual's financial resources affected in MS care increases by 20 times along the course of the disease, as well as with worsening disability ${ }^{13}$. These costs not only include social and unemployment benefits, but also include the support by other family members who stop working to look after the one with $\mathrm{MS}^{14}$. Therefore, it is possible that keeping people with MS in the labor market will help decrease these indirect costs and even improve their autonomy and well-being. Although the estimated prevalence of MS in Brazil is $20-30 / 100,000^{15,16}$, and there are many studies reporting clinical, radiological and immunological data regarding MS in Brazil, there is no objective information about the employment status of these patients.

Aiming to understand the occupational and employment status of patients with MS in Brazil, a country of continental size, we performed a survey with the primary objective of identifying their occupational and employability status and further analyzing this correlation with clinical and demographic factors.

\section{METHODS}

This was a cross-sectional, online, self-reported survey, performed from April through November 2017. The survey included 12 questions on demographic, social and occupational status at the moment of diagnosis and on the survey day, and information regarding the time interval from the first symptom to diagnostic confirmation and disease duration. The study was approved by the Universidade Federal de São Paulo Ethics Committee and all patients signed an online consent form.

The questionnaire had been previously presented to 10 patients with MS followed at the Neuroimmunology Clinic of the Universidade Federal de São Paulo to evaluate their comprehension of the content, and adjustments were made according to their feedback. Having a remunerated occupation was defined as holding a paid formal job, working autonomously or as part of a family business, or any informal activity with remunerated activity, as defined by the Instituto Brasileiro de Geografia e Estatística (https://www.ibge.gov. br). Age at onset was defined as the self-reported age of first symptoms attributed to MS, and age at diagnosis as the moment of diagnostic confirmation by a neurologist. Time to diagnosis was calculated as the time interval between the first symptom and diagnostic confirmation and disease duration as the time interval between first symptom and the date of survey completion, all in years. The survey was provided by the patient-committed organization Amigos Múltiplos pela Esclerose (AME, http://www.amigosmultiplos.org.br/) by e-mail and social media announcement.

Statistical analysis was performed using Microsoft Excel and GraphPad Prism version 7.00 (GraphPad Software Incorporated ). The D’Agostino-Pearson test was used to evaluate the departure from normality and data are presented as mean \pm standard deviation if they met normal distribution criteria, and median and quartiles if not. The unpaired t-test or Mann-Whitney were used when comparing two groups, and the chi-square or Fisher's exact test, when appropriate. Significance was set at $\mathrm{p}<0.05$.

\section{RESULTS}

A total of 847 surveys were returned from all five Brazilian geopolitical regions (north, northeast, centerwest, southeast and south). Forty-one surveys were duplicated and thus excluded; from the remaining 806, two more were excluded: one participant declined consent for the questionnaire to be used, and one stated not to have received the diagnostic confirmation of MS by a neurologist. Of the 804 included responses, 623 (77\%) were employed at the time of diagnosis but only 474 (59\%) reported being currently employed (Figure 1).

The analysis was performed in a stepwise approach. We first evaluated the whole cohort of 804 participants and then only those who had a remunerated activity at least once in their lifetime (753 participants) (Table 1). These steps were chosen in order to have a general view of the sample, compare the groups that had ever had any paid activity to the those that did not, and then evaluate the factors related to job retention only in the group that had ever had a remunerated activity (Table 2).

The 51 participants who had never been employed were younger and with less education, possibly representing people who had not yet entered the country's workforce. Of the 753 participants who were employed at least once in their lives, a longer time to diagnosis, longer disease duration and older age were the only evaluated MS factors correlated with becoming unemployed (Table 2). There was no difference among the five Brazilian geopolitical regions ( $p=3.692)$ or between genders (Tables 1 and 2).

Holding a university degree was positively associated with current employment status for the whole cohort as well as for those who were employed at least once in their lives $(\mathrm{p}<0.01)$ (Tables 1 and 2).

Finally, the evaluation of employment status change after the onset of the disease (Figure 2) disclosed that 55\% kept 


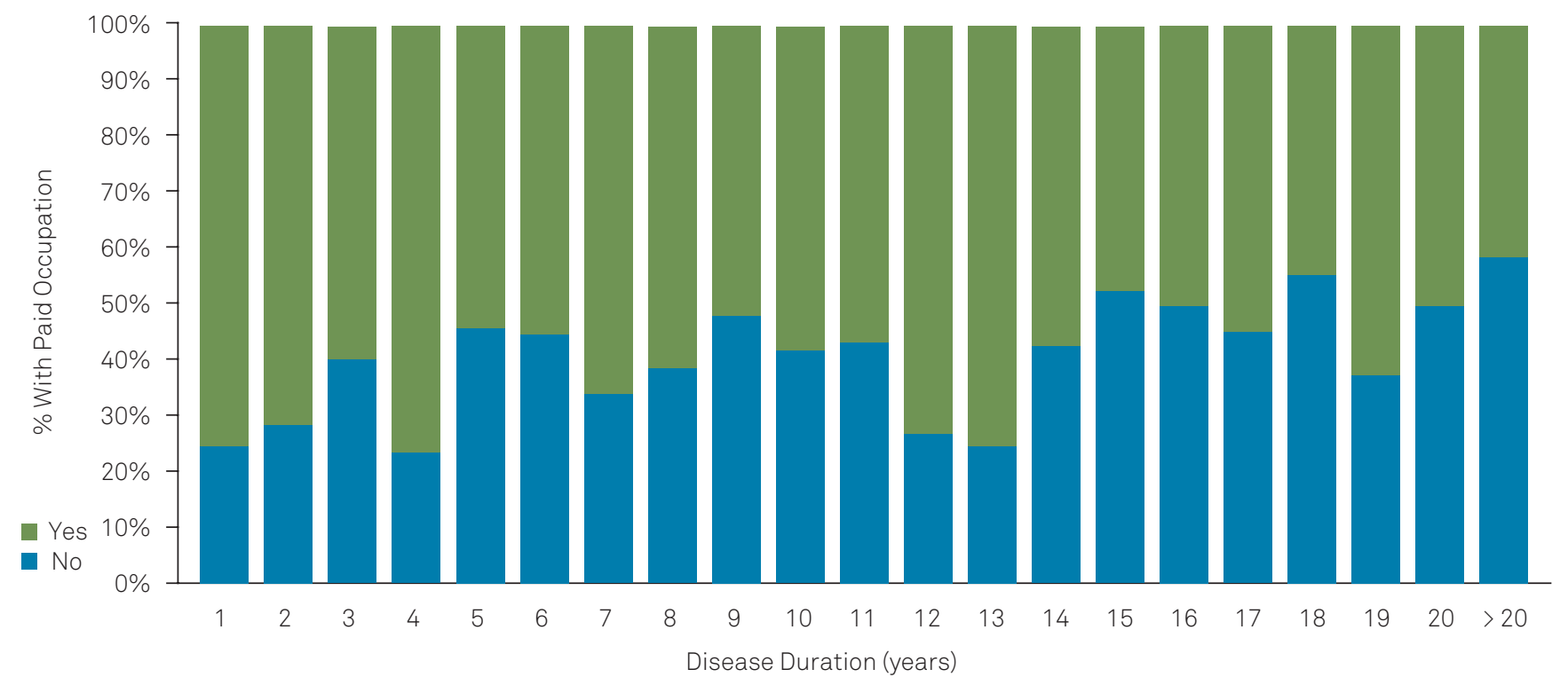

Figure 1. Employment status after the onset of MS.

Table 1. Clinical and demographic data of all participants $(n=804)$

\begin{tabular}{|c|c|c|c|c|}
\hline Category & $\begin{array}{l}\text { All patients } \\
\qquad(n=804)\end{array}$ & $\begin{array}{l}\text { Never employed } \\
\quad(n=51)\end{array}$ & $\begin{array}{l}\text { Employed once in } \\
\text { lifetime }(n=753)\end{array}$ & $\begin{array}{l}\text { p-value for never } \\
\text { being employed } \\
\text { (51 vs } 753 \\
\text { participants) }\end{array}$ \\
\hline \multicolumn{5}{|l|}{ Gender } \\
\hline Female & $673(84 \%)$ & $40(78 \%)$ & $633(84 \%)$ & 0.3253 \\
\hline Male & $131(16 \%)$ & $11(22 \%)$ & $120(16 \%)$ & \\
\hline Age at onset (years) & $28.3(22.0-33.7)$ & $20(16.8-23.3)$ & $27.8(22.6-33.9)$ & $<0.0001$ \\
\hline Age at diagnosis (years) & $31.9(24.9-36.2)$ & $20(17.7-25.8)$ & $30.3(25.7-36.3)$ & $<0.0001$ \\
\hline Time to diagnosis (years) & $2.7(0-4)$ & $1(0-1)$ & $1(0-4)$ & 0.0019 \\
\hline Current age (years) & $36.2(29.7-41.4)$ & $25.4(20.3-33.3)$ & $35.5(30.2-41.7)$ & $<0.0001$ \\
\hline Disease duration (years) & $7.9(3-11)$ & $5(3-9)$ & $6(3-11)$ & 0.0577 \\
\hline \multicolumn{5}{|l|}{ Education } \\
\hline Elementary & $31(4 \%)$ & $6(12 \%)$ & $25(3 \%)$ & $<0.0001$ \\
\hline High school & $236(29 \%)$ & $25(49 \%)$ & $211(28 \%)$ & \\
\hline University & $537(67 \%)$ & $20(39 \%)$ & $517(69 \%)$ & \\
\hline
\end{tabular}

Data are presented as median (1 ${ }^{\text {st }}-3^{\text {rd }}$ quartile)

their job and 27\% lost their job, $11 \%$ were, and remained, without wages, and $7 \%$ who were unemployed acquired a new job, revealing a dynamic change within these patients regarding being or not being employed.

\section{DISCUSSION}

The results of this national survey on the occupational and employment status of people with MS in Brazil found that $41 \%$ were unemployed within a mean of eight years after disease onset and were an average of 36 years of age with a high educational level. This is an important information, considering that the unemployment rate among the economically active population in Brazil for the last trimester of 2017 was only $13 \%{ }^{17}$.

This sample was representative of a large population of people with MS, as $84 \%$ were women, and clinical and demographic data resembled other Brazilian cohorts ${ }^{16}$. It is important to indicate that there was no difference between genders regarding employment status, demographic and clinical data. Additionally, employment retention was similar all over the country, which may imply that difficulties imposed on patients are ubiquitous and not related to their sex, or the degree of industrialization or technological development of the different states. 
Table 2. Clinical and demographic data of the 753 persons who were employed once in their lifetime $(n=753)$

\begin{tabular}{lccc}
\hline Category & $\begin{array}{c}\text { Unemployed today } \\
(\mathrm{n}=288)\end{array}$ & Employed today $(\mathrm{n}=465)$ & $\mathrm{p}$-value \\
\hline Gender & $248(86 \%)$ & $385(83 \%)$ & 0.2599 \\
$\quad$ Female & $40(14 \%)$ & $27.9(23-33.8)$ & 0.4411 \\
$\quad$ Male & $27.5(21.6-34.0)$ & $30(25.8-35.5)$ & 0.4918 \\
Age of onset (years) & $31.0(24.5-38.3)$ & $1(0-3)$ & $<0.0001$ \\
Age of diagnosis (years) & $1(0-5)$ & $34.8(30-40.4)$ & 0.0223 \\
Time to diagnosis (years) & $36.8(30.6-43.8)$ & $6(3-11)$ & $<0.0001$ \\
Current age (years) & $7(4-13)$ & $9(2 \%)$ & $<0.0001$ \\
Disease Duration (years) & $16(6 \%)$ & $108(23 \%)$ & $348(75 \%)$ \\
\hline Education & $103(36 \%)$ & &
\end{tabular}

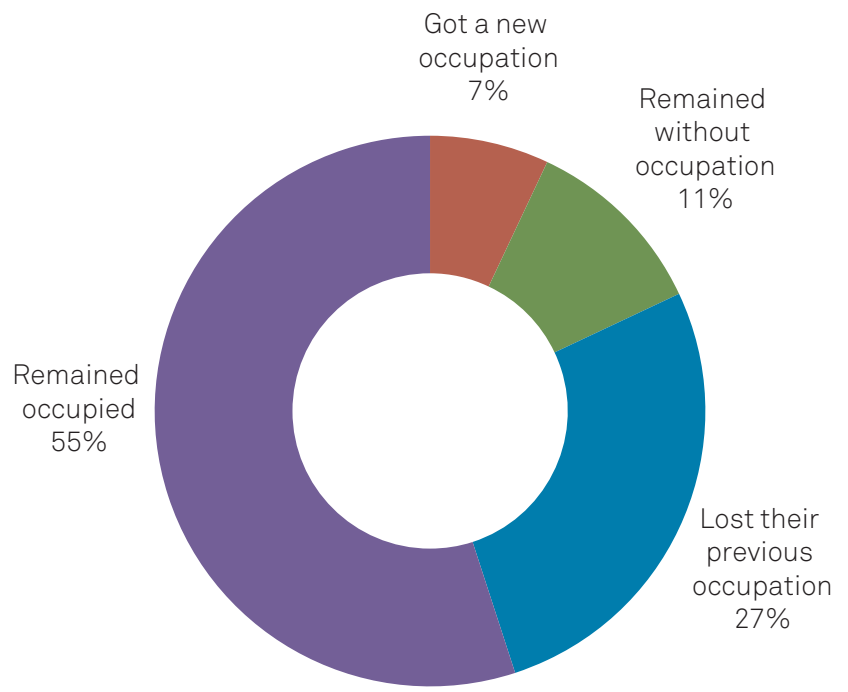

Figure 2. Dynamic changes in employment status after the onset of MS.

When considering only the patients who had a paid occupation at least once in their lifetime, taking longer to be formally diagnosed after the onset of symptoms, having the disease for a longer time and being older had a negative association with being currently employed (Table 2). This is not surprising as we know that longer disease duration is associated with higher neurological impairment, and longer time to diagnosis may imply delayed treatment, which is known to have a negative impact on maintaining neurological function ${ }^{18,19}$. This is corroborated by a study that evaluated the impact of treatment on employment status, reporting an unadjusted mean 10-year patient employment rate higher in those on disease modifying therapies (interferon beta and glatiramer acetate) versus no treatment $t^{20}$. The same study reported that 80 patients receiving a specific therapy were more likely to be employed after 10 years than the untreated patients.
The evaluation of employment status after disease onset showed a dynamic change beyond only people losing their job, but included those who retained their job or obtained a new occupation (Figures 1 and 2). Raggi et al. ${ }^{21}$ reported that age, perceived disability and depression were relevant factors associated with work difficulties in MS, which supports other determining factors besides those presented in this study, and evaluation of specific medical data, such as disability accumulation (either motor or cognitive), relapse rate, presence of psychiatric comorbidities, type of occupation, familial situation and others, would be necessary to better understand these changes. Becoming a recipient of social benefits may negatively influence the individual's desire to look for employment and increase the percentage of unemployment in this cohort. Even though this was not part of our objectives, this association would further strengthen the proposal of creating strategies for job retention, lessen the use of social financial resources and increase each individual's autonomy.

This study has limitations pertinent to any self-reported survey, including misdiagnosis, recall and interpretation bias of one's own symptomatic history, not having neurologic function and disability objectively measured and not analyzing the impact of specific therapies and interventions on employment status. Misdiagnosis of MS is estimated to occur all around the world, including research centers, and estimated to be around $2 \%$ to $5 \%$ of actual patients, including those receiving regular disease modification therapies ${ }^{22,23}$. Answering these questions requires a survey with a larger questionnaire and longer duration, including medical chart access and review, which is a much more detailed work that could not be completed in such a short time or include a large national sample size.

Nevertheless, considering that the estimated prevalence of MS in Brazil is 20-30/100,000 inhabitants ${ }^{15,16}$, this sample 
encompassed $2 \%$ of all patients, a substantial number for a pioneer project on this disease in Brazil, supporting the feasibility of an online survey to study MS-associated economic and social data. Our primary intention was to first describe and understand the employment rates cross-sectionally, to further develop a line of research including disability-associated employment status, autonomy, income and cost of disease.

In conclusion, the rates of unemployment in this cohort of patients with MS nearly doubled after disease onset, and less than two-thirds of highly-educated patients with MS in their productive years were employed at the time of the survey. A longer time to diagnosis may imply treatment delay, and strategies focusing on early diagnosis and adequate treatment may favor employment retention and decrease disability-related costs, such as social benefits and pension fund use.

Knowing the rate of unemployment and its associated factors can support the understanding of MS-related costs in Brazil and stimulate public and private initiatives that benefit patients in being more productive and less dependent on social benefits, thus gaining personal autonomy and reducing the disease's indirect costs.

\section{References}

1. Bienes G, Oliveira EM, Bichuetti DB. Esclerose múltipla. Rev Bras Med. 2014;71:9-14.

2. Giovannoni G, Butzkueven H, Dhib-Jalbut S, Hobart J, Kobelt G, Pepper G, et al. Brain health: time matters in multiple sclerosis. Mult Scler Relat Disord. 2016 Sep;9 Suppl 1:S548. https://doi.org/10.1016/j.msard.2016.07.003

3. Raggi A, Covelli V, Schiavolin S, Scaratti C, Leonardi M, Willems M. Work-related problems in multiple sclerosis: a literature review on its associates and determinants. Disabil Rehabil. 2016;38(10):93644. https://doi.org/10.3109/09638288.2015.1070295

4. Multiple Sclerosis International Federation - MSIF. Principles to promote the quality of life of people with multiple sclerosis. Waltham:: Multiple Sclerosis International Federation; 2014.

5. Moore P, Harding KE, Clarkson H, Pickersgill TP, Wardle M, Robertson NP. Demographic and clinical factors associated with changes in employment in multiple sclerosis. Mult Scler. 2013 Oct;19(12):164754. https://doi.org/10.1177/1352458513481396

6. Messmer Uccelli M, Specchia C, Battaglia MA, Miller DM. Factors that influence the employment status of people with multiple sclerosis: a multi-national study. J Neurol. 2009 Dec;256(12):198996. https://doi.org/10.1007/s00415-009-5225-0

7. Fantoni-Quinton S, Kwiatkowski A, Vermersch P, Roux B, Hautecoeur P, Leroyer A. Impact of multiple sclerosis on employment and use of job-retention strategies: the situation in France in 2015. J Rehabil Med. 2016 Jun;48(6):535-40. https://doi.org/10.2340/16501977-2093

8. Chiu CY, Chan F, Edward Sharp S, Dutta A, Hartman E, Bezyak J. Employment as a health promotion intervention for persons with multiple sclerosis. Work. 2015;52(4):749-56. https://doi.org/10.3233/WOR-152202

9. Bøe Lunde HM, Telstad W, Grytten N, Kyte L, Aarseth J, Myhr KM, et al. Employment among patients with multiple sclerosis-a population study. PLoS One. 2014 Jul;9(7):e103317. https://doi.org/10.1371/journal.pone.0103317

10. Kobelt G, Thompson A, Berg J, Gannedahl M, Eriksson J; MSCOI Study Group; European Multiple Sclerosis Platform. New insights into the burden and costs of multiple sclerosis in Europe. Mult Scler. 2017 Jul;23(8):1123-36. https://doi.org/10.1177/1352458517694432

11. Campbell JD, Ghushchyan V, Brett McQueen R, CahoonMetzger S, Livingston T, Vollmer T, et al. Burden of multiple sclerosis on direct, indirect costs and quality of life: national US estimates. Mult Scler Relat Disord. 2014 Mar;3(2):227-36. https://doi.org/10.1016/j.msard.2013.09.004

12. Salter A, Thomas N, Tyry T, Cutter G, Marrie RA. Employment and absenteeism in working-age persons with multiple sclerosis. J Med Econ. 2017 May;20(5):493-502. https://doi.org/10.1080/13696998.2016.1277229
13. Kobelt G, Berg J, Lindgren P, Fredrikson S, Jönsson B. Costs and quality of life of patients with multiple sclerosis in Europe. J Neurol Neurosurg Psychiatry. 2006 Aug;77(8):918-26. https://doi.org/10.1136/jnnp.2006.090365

14. da Silva NL, Takemoto ML, Damasceno A, Fragoso YD, Finkelsztejn A, Becker J, et al. Cost analysis of multiple sclerosis in Brazil: a cross-sectional multicenter study. BMC Health Serv Res. 2016 Mar;16(1):102. https://doi.org/10.1186/s12913-016-1352-3

15. Vasconcelos CC, Thuler LC, Rodrigues BC, Calmon AB, Alvarenga RM. Multiple sclerosis in Brazil: A systematic review. Clin Neurol Neurosurg. 2016 Dec;151:24-30. https://doi.org/10.1016/j.clineuro.2016.07.011

16. Pereira ABG, Lacativa MCS, Pereira FFC, Alvarenga RMP. Prevalence of multiple sclerosis in Brazil: A systematic review. Mult Scler Relat Disord. 2015 Nov;4(6):572-9. https://doi.org/10.1016/j.msard.2015.08.004

17. Instituto Brasileiro de Geografia e Estatstica - IBGE. Pesquisa Nacional por Amostra de Domicílios Contínua - PNAD Contínua. Rio de Janeiro: Instituto Brasileiro de Geografia e Estatstica; 2018.

18. Confavreux C, Vukusic S. Natural history of multiple sclerosis: a unifying concept. Brain. 2006 Mar;129(Pt 3):606-16. https://doi.org/10.1093/brain/awl007

19. Ziemssen T, Derfuss T, Stefano N, Giovannoni G, Palavra F, Tomic D, et al. Optimizing treatment success in multiple sclerosis. J Neurol. 2016 Jun;263(6):1053-65. https://doi.org/10.1007/s00415-015-7986-y

20. Campagnolo DI, Sun J, You X, Salter A, Laforet G, Fox R. Disease- modifying therapy use and employment status of multiple sclerosis patients: data from the North American Research Committee on Multiple Sclerosis. In: 15th Congress of the European Federation of Neurological Societies, Budapest, Hungary; 2011.

21. Raggi A, Giovannetti AM, Schiavolin S, Brambilla L, Brenna G, Confalonieri PA, et al. Older age, higher perceived disability and depressive symptoms predict the amount and severity of work-related difficulties in persons with multiple sclerosis. Disabil Rehabil. 2018 Apr:1-9. https://doi.org/10.1080/09638288.2018.1461937

22. Solomon AJ, Bourdette DN, Cross AH, Applebee A, Skidd PM, Howard DB, et al. The contemporary spectrum of multiple sclerosis misdiagnosis: A multicenter study. Neurology. 2016 Sep;87(13):1393-9. https://doi.org/10.1212/WNL.0000000000003152

23. Nicolau ZF, Oliveira EM, Bichuetti DB. Why this is not multiple sclerosis: a case based approach. Arq Neuropsiquiatr. 2015 Dec;73(12):985-92. https://doi.org/10.1590/0004-282X20150163 